\title{
Enabling adolescent boys to adopt attitudes that espouse gender equality and oppose violence against women and girls: Evidence from rural Bihar-Policy brief
}

Shireen J. Jejeebhoy

K.G. Santhya

Population Council

Follow this and additional works at: https://knowledgecommons.popcouncil.org/departments_sbsr-pgy

Part of the Demography, Population, and Ecology Commons, Domestic and Intimate Partner Violence Commons, Family, Life Course, and Society Commons, and the International Public Health Commons How does access to this work benefit you? Let us know!

\section{Recommended Citation}

Jejeebhoy, Shireen J. and K.G. Santhya. 2017. "Enabling adolescent boys to adopt attitudes that espouse gender equality and oppose violence against women and girls: Evidence from rural Bihar," Policy brief. New Delhi: Population Council. 


\section{Introduction}

More than a decade after the enactment of the Protection of Women from Domestic Violence Act, 2005, violence against women and girls remains widespread in India, and patriarchal norms and attitudes continue to underpin gender roles. While programmes that focus on empowering women and girls are necessary, they are not sufficient in themselves to prevent violence; men and boys are key players, and violence prevention programmes must include them. Moreover, by the time boys and girls reach adolescence, attitudes about unequal gender roles are already formed, and large proportions of girls and boys express attitudes justifying the right of a man or boy to control the behaviour of or perpetrate violence against women and girls. Therefore, it is important to help young girls and boys, especially boys, to adopt gender egalitarian values. Unfortunately, evidence on the kinds of programmes that may succeed in changing attitudes and practices of boys has been limited.

This brief describes an intervention, the Do Kadam Barabari Ki Ore (Two Steps Towards Equality) project, implemented among boys and young men in the ages 13-21 who were members of youth clubs that are supported by the Nehru Yuva Kendra Sangathan (NYKS) programme1 of the Ministry of Youth Affairs and Sports. The project was undertaken by the Population Council together with partners, the Centre for Catalysing Change (C3) and the London School of Hygiene and Tropical Medicine, and with support from UKaid. The brief also presents the effect of exposure to the project in transforming gender role attitudes of boys and, particularly, their attitudes toward violence against women and girls.

\section{Do Kadam Barabari Ki Ore}

The intervention comprised a mix of gender transformative life skills education and cricket-coaching. Typically, boys met for two hours a week: one hour was devoted to a gender transformative life skills education programme and the other hour to cricket-coaching and games sessions. The life skills curriculum was delivered over 42 weekly sessions and covered such broad topics as gender discrimination, notions of masculinity, and violence against women and girls. Sessions were delivered by club members who were selected as peer mentors and who had undergone several pre-programme and refresher training programmes, often together with core trainers from the implementing agency, C3 India. The cricket-coaching and games component was intended to convey a sense of fair play, team spirit, sportsmanship, and resolution of conflict in non-violent ways, aside from improving cricketing skills of the boys.

We used a cluster randomised trial (CRT) design, with 15 Nehru Yuva Kendra Sangathan (NYKS) clubs each in intervention and control arms, to evaluate the project. We interviewed a total of 1,149 boys from intervention and control arms before we launched the intervention in 2013; of these, 90 percent of boys $(1,033)$ were successfully re-interviewed two months after completing the intervention. Additionally, we held in-depth interviews with selected boys who had participated in the survey from the intervention clubs at three points in time-before launching the intervention (baseline), about 6-7 months into the intervention (midline), and after the intervention was over (endline); 32 boys were interviewed at baseline, of whom 24 responded in all three interviews.

Boys in our study were socialised in a context that condones gender discrimination and violence against women and girls. As a result, as seen in the figure below, at the baseline survey, relatively small proportions espoused gender egalitarian attitudes or rejected attitudes justifying the right of boys and men to control their sister, wife, and girlfriend and to perpetrate violence on a girl or a wife.

${ }^{1}$ Under this programme, youth clubs are established at the village level and are open to all those in the ages 13-35. The objective of youth clubs is to offer young people leadership development opportunities through a range of activities intended to raise awareness, encourage participation in sports, build leadership skills and a sense of citizenship, and engage youth in community development activities.

POPULATION COUNCIL

Ideas. Evidence. Impact.

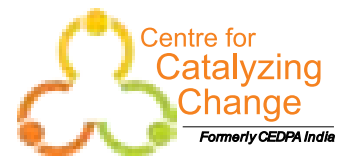

LONDON SCHOOL of HYGIENE \&TROPICAL MEDICINE 
Figure 1: Gender role attitudes and notions of masculinity and perceptions about the right of boys and men to control the behaviour of their sister, girlfriend, and wife, among boys in the ages 13-21 by treatment arms, baseline survey, 2013

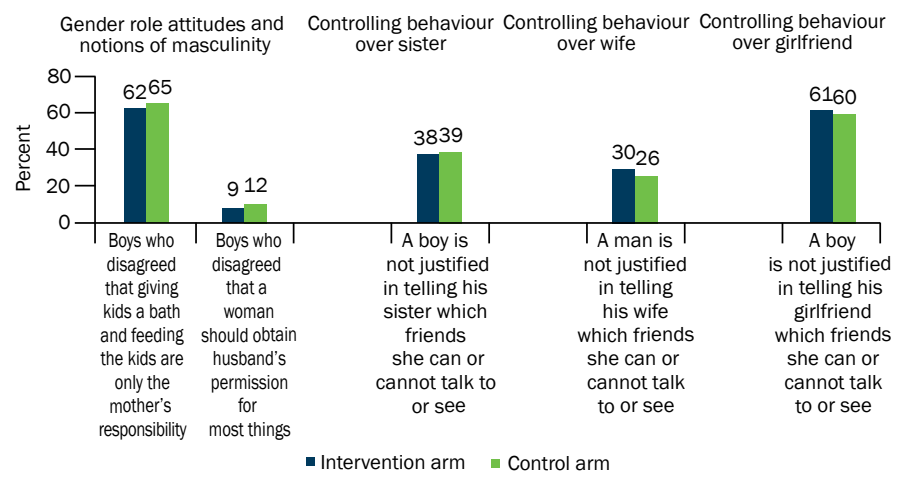

\section{Participation of the boys in Do Kadam Barabari Ki Ore programme}

Most boys in the intervention clubs participated in Do Kadam programme; however, somewhat fewer boys attended the sessions regularly, that is, weekly, whenever sessions were held or at 2-3 times in a month. Most boys reported that they had both liked and learned something new from the life skills sessions on each topic, looked forward to sessions, and found the peer mentors approachable.

A respondent's favourable reaction to Do Kadam activities is given below.

Yes, I liked it a lot and had fun too. Because we were taught about how to talk to people, how to live well in the home, to study well, to help in household chores, not to harass girls, to live in peace with everyone, and we were taught sports as well..... Whatever sessions I attended I liked it. [Aged 15, completed Class 7, endline]

Figure 2: Participation of the boys in life skills sessions and cricket sessions conducted as part of the Do Kadam Barabari Ki Ore programme, intervention clubs, endline survey, 2015

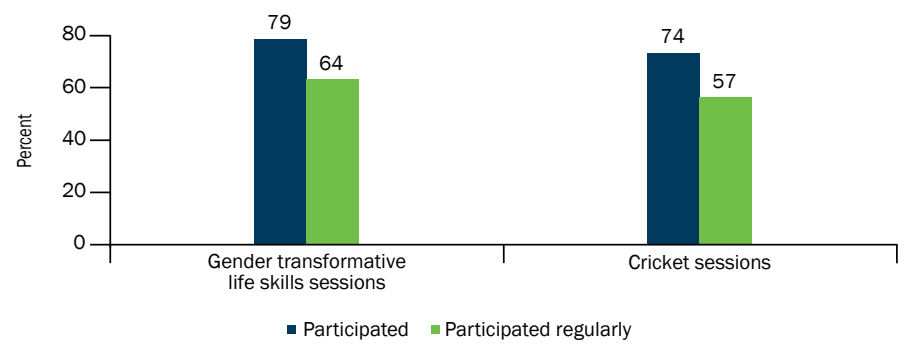

\section{How did Do Kadam Barabari Ki Ore programme influence the lives of boys?}

Participation in Do Kadam programme influenced the lives of boys positively in many ways. It succeeded in making the attitudes of boys in the intervention clubs more gender egalitarian, in changing notions of masculinity, and in enabling them to reject the notion of the right of men and boys to exercise control over women and girls and perpetrate violence on them. Findings from in-depth interviews confirm, moreover, that notions of both masculinity and men's right to perpetrate violence had been considerably tempered over the three interviews, with more boys at the endline expressing the view that violence is unacceptable, and, again, more boys describing various legal and other options for women who experience marital violence.

\section{Gender role attitudes became more egalitarian and notions of masculinity became more positive}

At the conclusion of the programme, a significantly larger proportion of boys in the intervention than control clubs expressed egalitarian gender role attitudes and positive notions of masculinity. For example, they agree that childcare is the joint responsibility of the mother and father or that a woman need not obtain her husband's permission in most situations. Changes in gender role attitudes are, as reflected in the two responses of a study participant in the course of his midline and endline interviews, respectively, are given below.

Midline: Parents in fear of being insulted in the society don't give that much freedom to girls as they do to the boys. They feel that if the girl roams around here and there, something wrong may happen with her like someone may trouble her or something else which will be insulting so that is why they don't let her go out a lot. I think this is right, because if something wrong happens with her, people will talk about her saying that she has become bad and keeps roaming here and there. That is why she shouldn't be allowed to go out. She can go out for some work and then be at home.

Endline: Girls also have the right to study, they have the right to go out and enjoy just like the way a boy has. [Aged 18, completed Class 9]

Figure 3: Percentage of boys who disagreed with selected statements reflecting traditional gender role attitudes and notions of masculinity by treatment arms, endline survey, 2015

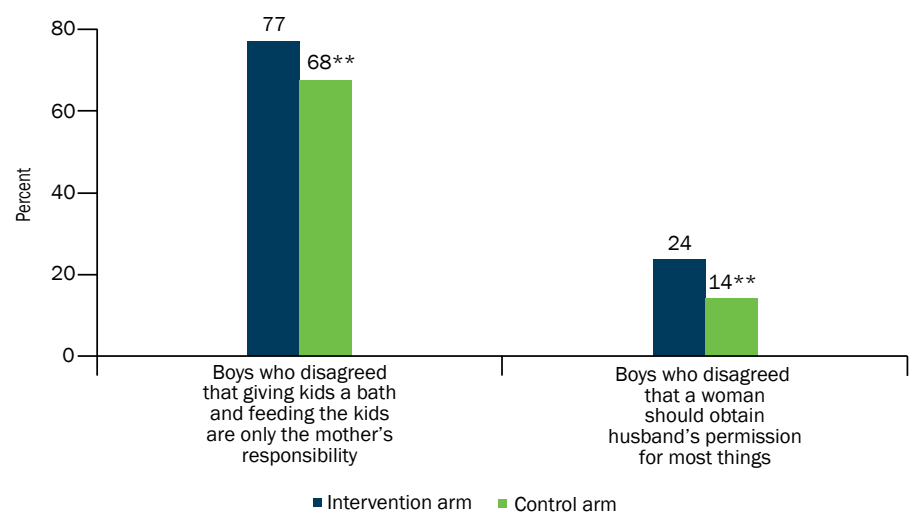

Note: ** indicates that the difference between intervention and control arm is significant at $p \leq 0.01$ 


\section{Peers became more respectful of boys acting in gender equitable ways}

There was strong evidence, in addition, to suggest that more boys in intervention than control clubs believed that their peers would respect boys who demonstrated nontraditional behaviours, such as helping in housework, sharing personal problems with a peer, refusing to participate in a physical fight, and refusing to beat their wife even if she has 'erred'. One in five boys in the intervention clubs compared with one in eight in the control clubs believed that their peers would respect them for demonstrating non-traditional behaviours in at least three of the four situations presented to them.

Figure 4: Percentage of boys reporting that they would be respected by their peers for behaving in non-traditional ways in selected situations by treatment arms, endline survey, 2015

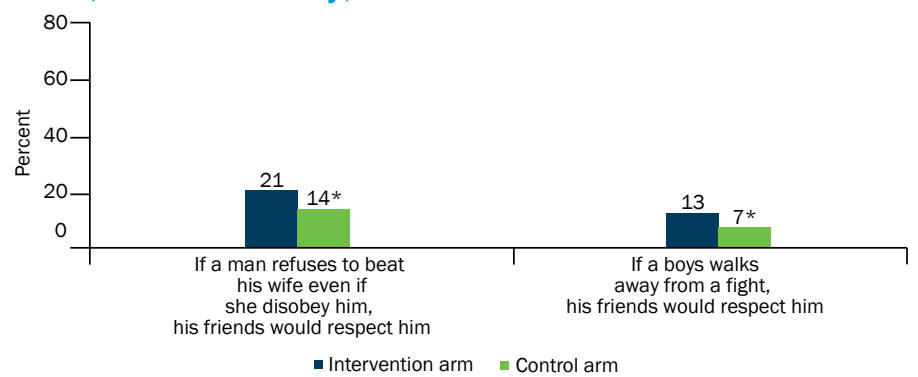

Note: * indicates that the difference between intervention and control arm is significant at $p \leq 0.05$.

More boys rejected the notion of the right of men and boys to exercise control over the females in their life

Again, there was strong evidence that exposure to the intervention had a significant effect on making boys denounce attitudes justifying the right of men and boys to control the females in their life. Thus, boys in the intervention clubs were significantly more likely than those in the control clubs to reject the right of boys or men to control their sister, wife, or girlfriend.

Figure 5: Percentage of boys who rejected the right of men and boys to control selected behaviours of their sister, girlfriend, and wife by treatment arms, endline survey, 2015

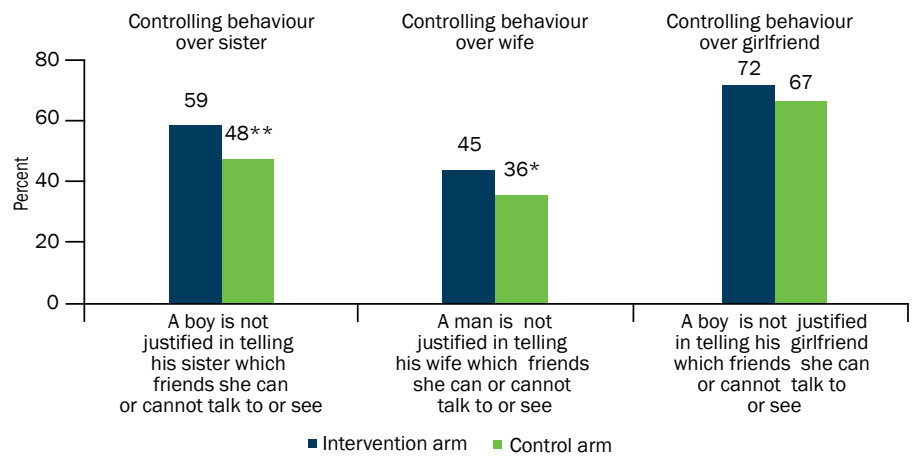

Note: * and $* *$ indicate that the difference between intervention and control arm is significant at $p \leq 0.05$ and $p \leq 0.01$, respectively.

\section{More boys found violence against women and girls} unjustifiable

Findings also confirm that a larger proportion of boys in the intervention than control clubs reported that violence against women and girls is non-acceptable. A response to this effect is reproduced in the following.

Endline: No, according to me there is no such situation where it is right for a man to beat his wife. No, not even when she is having an extramarital affair. If so, he should talk to her and make her understand that what she is doing is wrong and because of that everything will be ruined, and if she doesn't stop, then he will leave her, like this he should make her understand, hitting her is wrong.... In the club, they told us that when the husband gets involved in an extramarital affair, does his wife beat him? She too talks to him and makes him understand, so we should too make her understand. [Aged 16, completed Class 10]

Figure 6: Percentage of boys who rejected the right of men and boys to perpetrate violence against women and girls under selected circumstances by treatment arms, endline survey, 2015

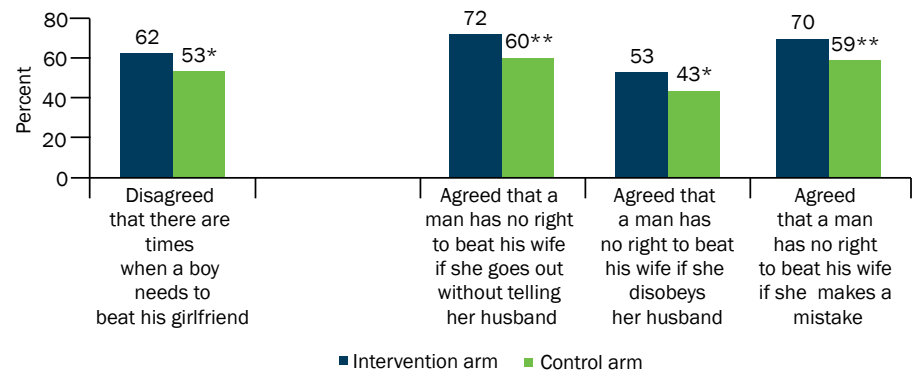

Note: * and ** indicate that the difference between intervention and control arm is significant at $p \leq 0.05$ and $p \leq 0.01$, respectively.

Indeed, attitudes about the acceptability of violence against women and girls had changed from justifying wife-beating in most situations to justifying wife-beating only in very extreme situations, such as in instances of extramarital relations. However, by the time of the endline survey, justifying wife-beating even in extreme situations was considered unacceptable as seen in the narratives below.

Baseline: If the wife does something wrong they should try and explain to her softly and calmly. Beating is not a good solution, but if she doesn't listen to her husband even after he has explained to her, then he should beat her up.

Midline: It is wrong to be violent. Explaining and understanding can solve any problem. But in some cases it does happen that the wife becomes better because of being scared of hitting but not in most cases.

Endline: Whatever is the case, hitting is not right. It is important to make the other person understand. A woman will understand if there is some discussion, whereas by hitting no one understands. Yes such men 
should be punished.... If a woman has an affair with another man, then too the husband should not hit her, but it is important to explain to her. If she still doesn't agree then her parents should be called and told about their daughter. Women are not stupid, they will understand without beating. [Aged 17, completed Class 11]

\section{Programme recommendations}

The Do Kadam Barabari Ki Ore intervention has demonstrated considerable impact on changing traditional norms and attitudes among boys and in laying the groundwork for reductions in the perpetration of violence against women and girls. The model is acceptable, effective, and appropriate for up-scaling into existing boys' groups through both the Nehru Yuva Kendra Sangathan (NYKS) platform and other group opportunities.

- While up-scaling, the design of programmes needs to take into consideration boys' own preferences with regard to components other than gender transformative life skills education. Our programme was designed keeping in mind expressed interest of the boys in a cricket-coaching component. However, in other settings, boys may express interest in other sports and even components other than sports, such as livelihood skill building, or training in the
English language, and/or computer skills. It is important, therefore, to engage with the concerned platform to arrive at a mutually acceptable intervention design prior to initiating the intervention.

- Our findings have highlighted that a peer-led model is indeed promising but calls for ongoing investment in peer mentor capacity building. While the peer mentor model is ideal in many ways to encourage behaviour change, in our programme, it required extensive efforts to change the norms held by peer mentors and to build their capacity and confidence about imparting the programme. An up-scaled programme would need to invest in preintervention and regular refresher training programmes for peer leaders as well as supportive supervision of intervention progress.

- We caution that in this gender-stratified socio-cultural context, change is slow, and although the project succeeded in engendering the attitudes and practices of large numbers of boys, many boys continued to display traditional attitudes and practices, calling for greater efforts, perhaps in forums reaching even younger boys, to transform norms and behaviours of the young.

\section{Acknowledgements}

The authors would like to gratefully acknowledge insightful comments that Ann Blanc, Mamta Kohli and Nel Druce made on earlier versions of this brief; Komal Saxena helped in the design and production of this brief. The authors also gratefully acknowledge the financial support provided by the UK Department for International Development (DFID).

This brief has been developed based on the following publication: Jejeebhoy, S.J., Rajib Acharya, Neelanjana Pandey et al. 2017. The effect of a gender transformative life skills education and sports-coaching programme on the attitudes and practices of adolescent boys and young men in Bihar. New Delhi: Population Council.

Suggested citation: S. J. Jejeebhoy and K. G. Santhya. 2017. Enabling adolescent boys to adopt attitudes that espouse gender equality and oppose violence against women and girls: Evidence from rural Bihar, Policy Brief. New Delhi: Population Council.

\section{Population Council}

\section{Population Council}

Zone 5A, Ground Floor

India Habitat Centre, Lodhi Road

New Delhi, India 110003

Phone: +91-11-2464 2901

Email: info.india@popcouncil.org

The study has been funded by UK aid from the UK Government; however the views expressed do not necessarily reflect the UK Government's official policies.

\section{POPULATION COUNCIL \\ Ideas. Evidence. Impact.}
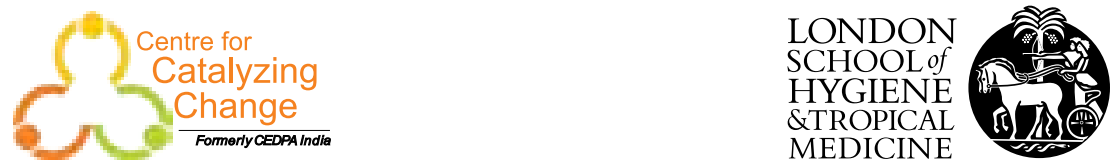

The Population Council conducts research and delivers solutions that improve lives around the world. Big ideas supported by evidence; it's our model for global change.www. popcouncil.org 